Abstract P26 Table 1. Outcome of a negative T spot test.

\begin{tabular}{|c|c|c|c|c|c|}
\hline $\begin{array}{l}\text { Negative } \\
\text { T spot } \\
\text { test }\end{array}$ & $\begin{array}{c}n \\
(199)\end{array}$ & $\begin{array}{l}\text { Chem } \\
\text { oprop } \\
\text { hylaxi } \\
s \\
\text { given }\end{array}$ & $\begin{array}{l}\text { CXR changed } \\
\text { management? }\end{array}$ & $\begin{array}{c}\text { Patient outcome } \\
\text { (immuno-suppressant) }\end{array}$ & $\begin{array}{c}\text { LTBI } \\
\text { reactivation }\end{array}$ \\
\hline $\begin{array}{c}\mathrm{CXR} \\
\text { normal }\end{array}$ & $\begin{array}{l}77.9 \% \\
,(155)\end{array}$ & 0 & No & $\begin{array}{l}5 . \% \text { (8) not commenced } \\
7.1 \% \text { (11) patient declined } \\
0.6 \% \text { (1) stopped (recurrent } \\
\text { LRTIs) } \\
0.6 \% \text { (1) stopped (new renal } \\
\text { CA) }\end{array}$ & 0 \\
\hline $\begin{array}{l}\text { CXR } \\
\text { abnormal } \\
\text { (possible } \\
\text { previous } \\
\text { TB) }\end{array}$ & $\begin{array}{l}8 \% \\
(16)\end{array}$ & 0 & No & $\begin{array}{l}6.25 \% \text { (1) not commenced } \\
\text { (disease activity too low) } \\
625 \% \text { (1) stopped (leg ulcers) } \\
6.25 \% \text { (1) stopped (wheeze) } \\
6.25 \% \text { (1) stopped (leucopenia) }\end{array}$ & 0 \\
\hline $\begin{array}{c}\text { CXR } \\
\text { abnormal } \\
\text { (other) }\end{array}$ & $\begin{array}{l}6 \%, \\
(12)\end{array}$ & 0 & No & $\mathbf{8 3} \%$ (1) patient declined & 0 \\
\hline $\begin{array}{l}\text { CXR } \\
\text { previousl } \\
\text { y normal }\end{array}$ & $\begin{array}{l}2.5 \%, \\
(5)\end{array}$ & 0 & No & $20 \%$ (1) patient DNA f $1 u$ & 0 \\
\hline $\begin{array}{l}\text { CXR not } \\
\text { done }\end{array}$ & $\begin{array}{l}5.5 \% \\
(11)\end{array}$ & 0 & $\mathrm{~N} / \mathrm{A}$ & $\begin{array}{l}\text { 9.1\% (1) patient declined } \\
\mathbf{4 5 . 5 \%}(5) \text { not commenced } \\
\text { (disease activity to low) }\end{array}$ & 0 \\
\hline
\end{tabular}

patients who were being considered for immuno-suppresant therapy.

Methods All IGRAs requested from Glasgow Royal Infirmary (GRI) over a 21 month period were retrospectively assessed for the following: patient history, test indication and result, CXR report and patient outcome. GRI serves the most deprived population in the UK. A single laboratory provides TB bacteriology for the whole of Glasgow, and is the sole provider of IGRA testing for LTBI utilising the 'T-Spot.TB'.

Results Between August 2010-May 2012, 354 T-Spot.TB tests were performed. Planned immuno-suppressant therapy was the indication in $70 \%(\mathrm{n}=248)$; etanercept was the most commonly proposed drug $(32 \%, \mathrm{n}=78)$, followed by adaluminab $(29 \%, \mathrm{n}=72)$, anti-TNF not otherwise specified $(11 \%, \mathrm{n}=28)$ and infliximab $(6 \%, \mathrm{n}=15)$. Of those for whom immunosupression was the indication, $80 \%(\mathrm{n}=199)$ of T-Spot.TB tests were negative, $17 \%(\mathrm{n}=41)$ indeterminate and $3 \%(\mathrm{n}=8)$ positive. A CXR was performed in all but $6 \%(\mathrm{n}=11)$. CXR findings and patient outcomes for patients with negative T-Spot. TB tests are summarised in table 1 . All 16 abnormal CXRs were referred to a TB specialist for review and none had chemoprophylaxis commenced or any alterations in their management recommended.

Conclusions With increasing use of IGRAs, new guidance on screening for LTBI prior to anti-TNF therapy is required. In our cohort of 248 patients, the majority had a negative T-spot test reflecting that despite high levels of deprivation TB prevalence in Glasgow is low. CXR did not alter patient management, TB chemoprophylaxis was not given in any case and there were no cases of LTBI reactivation or de novo TB within the follow-up period (11-32 months). We propose that if IGRA is negative, CXR is not required as part of screening for LTBI prior to antiTNF therapy.

\section{P27 DOES A DIRECT RADIOLOGY REFERRAL SYSTEM TO A RAPID ACCESS TUBERCULOSIS CLINIC IMPROVE TB DIAGNOSIS?}

CA Lynch, S Sabah, M Dedicoat, H Kunst; Birmingham Heartlands Hospital, Birmingham, United Kingdom

10.1136/thoraxjn-2013-204457.177
Abastract P27 Table 1. Number of days between radiology rapid access referral, clinic review and initiation of treatment in subgroups of active TB cases.

$\begin{array}{lll}\text { Smear positive } & \text { Culture positive } & \text { Extrapulmonary } \\ \text { pulmonary TB }(n=47) & \text { pulmonary TB }(n=33) & \text { TB }(n=31)\end{array}$

Number of days between radiology referral to rapid access $T B$ clinic and clinic review Admitted

$<5$ days

5-14 days

2

14

28

42

$>14$ days

3

8

$16 \quad 18$

Number of days between radiology referral to rapid access TB clinic and starting anti-TB

treatment

Admitted

$<5$ days

5-14 days

$14-28$ days

$>28$ days

$\begin{array}{lll}2 & 4 & 2 \\ 13 & & 5 \\ 23 & 8 & 5 \\ 5 & 9 & 4 \\ 4 & 12 & 15\end{array}$

Introduction Delayed diagnosis of active pulmonary tuberculosis (TB) is common and significantly contributes to transmission especially in smear-positive pulmonary TB. Persons with symptoms suggestive of pulmonary TB often have chest radiographs prior to sputum examination and clinical assessment by a specialist. There is no NICE guidance on direct radiology referral pathways to a rapid access $\mathrm{TB}$ clinic. This question prompted us to examine all cases referred by the radiology department to our rapid access TB clinic at a centre of England tertiary referral centre.

Method We conducted a retrospective study of consecutive patients with features of active $\mathrm{TB}$ on chest radiograph referred by the radiologists to the rapid access TB clinic from 2008 to 2013. All chest radiographs were reviewed by TB consultants who arranged clinic appointments according to the degree of clinical suspicion of active disease.

Results 223 cases were referred during the period of November 2008 to May 2013. All patients were requested to attend the TB clinic, 4 patients did not attend clinic.

Of 223 cases, 111 patients (50\%) were diagnosed with active TB. Mean age of all active cases was 38 years (range 16-83 years) with a male predominance $(62,56 \%)$. Of 111 cases, 61 (55\%) were from Indian subcontinent, 22 (19\%) from Africa, 25 (22\%) were UK born and 3 cases were born in other countries.

80 cases had pulmonary TB (72\%), of whom 47 (59\%) were smear positive. 28 cases $(25 \%)$ had extra pulmonary disease, two cases had disseminated miliary disease and one case was diagnosed clinically.

Table 1 indicates that 102 (92\%) cases were seen in clinic within 14 days of rapid access radiology referral and 80 (72\%) were started on anti-TB treatment within 28 days of radiology referral. 103 patients (93\%) had fully sensitive TB with 8 resistant cases.

Conclusion Direct radiology referral of cases with chest radiographs suggestive of pulmonary $\mathrm{TB}$ to a rapid access TB clinic can hasten diagnosis of active $\mathrm{TB}$ and should be included in NICE guidance.

\section{P28 NOVEL BAYESIAN NETWORK ANALYSIS ALLOWS SYSTEMATIC COMPARISON OF THE SAFETY AND EFFICACY OF DIFFERENT LATENT TB INFECTION TREATMENTS}

${ }^{1}$ HR Stagg, ${ }^{2} \mathrm{D}$ Zenner, ${ }^{2} \mathrm{RJ}$ Harris, ${ }^{3} \mathrm{~L}$ Munoz, ${ }^{4} \mathrm{M}$ Lipman, ${ }^{1}$ I Abubakar; ${ }^{1}$ University College London, London, UK; ${ }^{2}$ Public Health England, London, UK; ${ }^{3}$ Bellvitge University Hospital- 